\title{
PDE5A wt Allele
}

National Cancer Institute

\section{Source}

National Cancer Institute. PDE5A wt Allele. NCI Thesaurus. Code C95468.

Human PDE5A wild-type allele is located in the vicinity of $4 \mathrm{q} 27$ and is approximately 135

kb in length. This allele, which encodes cGMP-specific 3',5'-cyclic phosphodiesterase

protein, is involved in the regulation of second messenger metabolism. 